\title{
Digital economy and green economy: rural unemployment and territorial self-development in Russia
}

\author{
Igor N. Aleksandrov ${ }^{1, *}$, and Marina Yu. Fedorova ${ }^{2}$ \\ ${ }^{1}$ Peter the Great St.Petersburg Polytechnic University (SPbPU), Polytechnicheskaya 29, St. \\ Petersburg, 195251, Russia \\ ${ }^{2}$ Institute of Economics of the Karelian Research Centre of the Russian Academy of Sciences, A. \\ Nevskogo 50, Petrozavodsk,185030, Russia
}

\begin{abstract}
The unemployment, low quality of life and low salaries are the main problems of the Russian countryside which is in the process of dying now. The out-migration from rural territories to big cities such as SaintPetersburg and Moscow takes place all other the country. It damages the regional economy due to the outflow of human resources. We assume that the rate of unemployment in rural Russia is higher than statistics data shows, because the majority of unemployed do not want to be registered by state bodies. A survey of countryside local residents showed that they need extra money, they are not familiar with entrepreneurship through the Internet, they are interested in making money through the Internet. Taking in mind the realm of the digitalization and post-industrial economy, we propose to renovate the rural economy with the help of self-development tools that involve the local community in the entrepreneurship in digital economy. That is why we propose to work with locals, teaching them to earn money with the help of Internet.
\end{abstract}

\section{Introduction}

At the present time, the largest part of the Russia is not used appropriately to provide economic profit to the country because the main population prefers to live at cities due to availability of infrastructure and employment possibilities. $68,3 \%$ of the Russian population is concentrated in less than $21 \%$ of the land surface. On the other hand, another tendency is that people from big cities are getting tired of densely populated cities and are looking for less populated places with better environment. Some individuals are even not afraid of choosing abandoned or deserted areas. Moreover, the retired people would prefer the countryside to the life in big cities, but the absence of medical infrastructure makes the out-migration impossible. We assume, the more systematic settlement of the vast territory of Russia would reduce the impact on cities' infrastructure that results the reduce of the impact on the environment. On the other hand, the more systematic settlement of the Russian surface would allow to care about natural resources which are being abandoned,

\footnotetext{
* Corresponding author : a7830298@gmail.com
} 
destructed and damaged both by tourists and locals at the present time. Tourists come to relax from of big cities, but locals do not possess enough resources to care appropriately about their own environment.

According to Victor P.A., Jackson T., the "principal goal of the green economy is to deliver prosperity to individuals and communities. Prosperity demands not only the provision of goods and services but also security in employment and stability in markets" [1]. That also means that one of the main objectives of the green economy is the growth of employment. That is why to achieve the development of the green economy in Russia the conditions of rural population must be revised and improved. According to T. V. Morozova $\mathrm{T}$.V et al. at the present time low salaries, lack or even absence of infrastructure causes migration from the countryside to cities [2].

Our hypothesis was that locals of the countryside can work either remotely or sell their goods and products with the help of Internet services and earn money. The problem is that rural people do not aware of special tools, services and strategirs to earn money via Internet. The interview undertook among rural people to research the familiarization with the phenomenon of remote work and the interest in earning money with the help of Internet showed that there is the share of people from 25 to 70 years old who are interested in earning money via Internet but they do not possess appropriate knowledge is more than 50 $\%$.

\section{Materials and Methods}

For the research the village Tolvuya of the Medvezhiegorsky District of the Republic of Karelia was chosen. Medvezhiegorsky District had always been a remote one in the whole Republic of Karelia. The main resources of the Medvezhiegorsky District were always considered to be its special climate and architectural and cultural climate. The most attractive architectural monuments we can see on Kizhi Island, one of the most touristic places in the Republic of Karelia. But the economy of the Medvezhiegorsky District does not benefit from this place because all the taxed are paid to the capital of the Republic of Karelia. There are no other important profitable enterproses at the territory of the Medvezhiegorsky District, particularly situated not in its center Medvezhiegorsk.

The main villages of the District are Velikaya Guba, Shunga and Tolvuya. All the villages got its main profit from "sovkhoz", state-owned farms created in the USSR. Today they are not profitable and pay low salaries. Velikaya Guba is situated very close to Kizhi Island protected by UNESCO. Whatever a lot of tourists go to visit only the architectural monuments of Kizhi Island we assume that Velikaya Guba benefits to some extent from the proximity with this tourist attraction. The village Shunga is closer to the center of the District then Tolvuya. That is why we chose Tolvuya as an example of a remote village with the population higher than 1000 inhabitants.

According to the statistics data of the Republic of Karelia the population of the whole Medvezhiegorsky District amounts 27934 and its rural share takes 7401 people. According to the data on the 1th of January 2017 the population of the village Tolvuya amounted 1133 people.

The research was implemented according to the stratified sampling with the use of proportionate allocation strategy. Then simple random sampling was applied within each stratum. The questionnaire was implemented both via Internet and with the help of telephone calls due to the fact that the retired people prefer to talk by phone and the youth prefers more rapid interviews via Internet. The whole amount of interviewees was 158 people which makes a little bit more than $10 \%$ of the whole population of the village Tolvuya. The sampling was divided into three main groups of people, the first one was from 25 to 45 years old, working, not retired. The second group was from 46 to 55 years 
old, the middle-aged people, close to the retirement. The third group of interviewees was from 56 to 70 years old, the retired. The amount of each stratum was calculated according the amount of corresponding stratum of rural population in the Republic of Karelia. The interview was arranged with the closed-ended and one open-ended question.

\section{Results}

For the open-ended question "Which is the main problem to be solved in your village?" the most popular answer was "the unemployment" and "low salaries".

For the question "Do you want to make extra money?" (Fig. 1) 85,7\% of women $46-$ 55 gave positive answer, 14,3\% women answered "no" and $100 \%$ of men of $46-55$ answered "yes" for the same question.

The respondents of $56-70$ years, both women and men old also showed the interest to make extra money giving positive answers correspondingly $73 \%$ and $65,3 \%$.

Among respondents of $26-45$ years old for the question "Do you want to make extra money?" $100 \%$ of individuals answered "Yes". It should be mentioned that the respondents gave positive question not depending on whether they work or not, live with a family or alone.

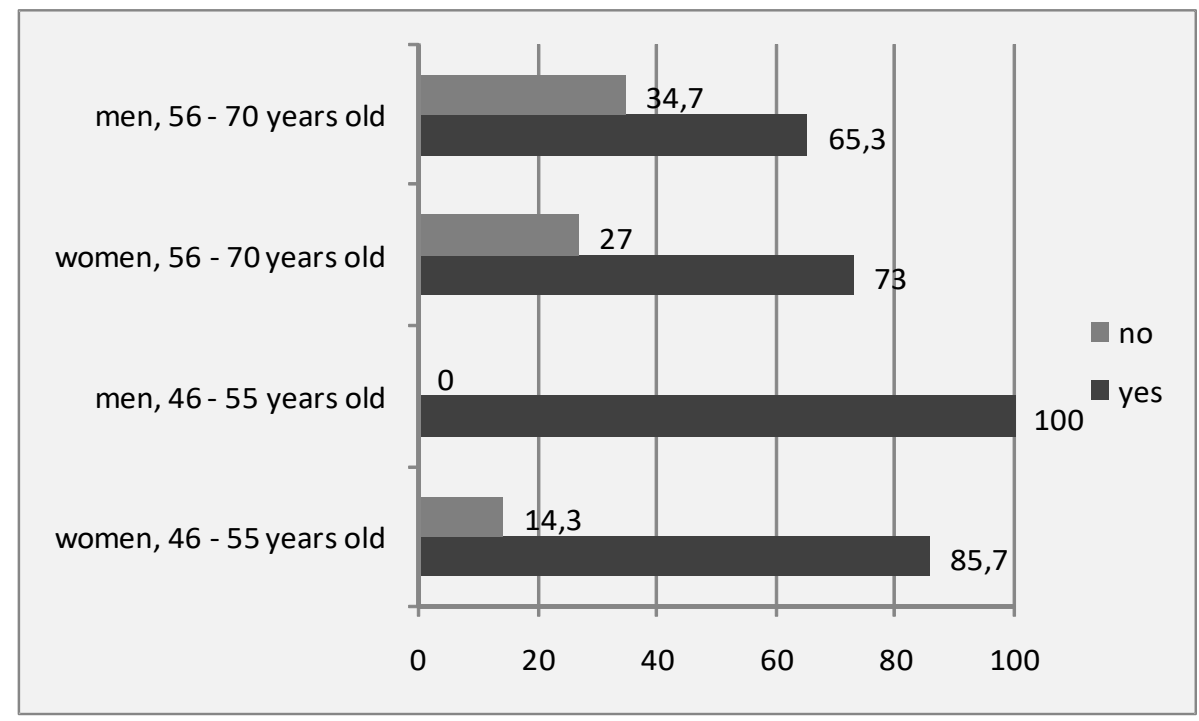

Fig. 1. Do you want to make extra money? (women and men, $46-70$ years old, \%).

For the question "Are you earning money with the help of Internet" $100 \%$ of respondents of all ages answered "No".

The Figure 2 shows us the perceptions of work with the help of Internet tools by rural people. The numbers in the Figure 2 correspond the answers as following,

1 - "Yes, I know nothing about it and I have never tried";

2 - "Yes, I want to improve my skills and make more money";

3 - "No, I am not interested in earning money via Internet";

4 - "No, I know everything about it and I am earning enough money via Internet now".

In spite of the positive answer about the wish to earn extra money not everybody answered positively to the question "Do you want to learn how to make extra money with the help of Internet?" (Fig. 2). The women of all ages are more interested in making extra money via Internet. The share of men interested in making money via Internet makes from 30 to $40 \%$. As we see, nobody is making money on the Internet at the present time, but 
there are men and women who are interested in such kind of work. So we assume that the middle-aged men and women face difficulties when want to start making money on the Internet due to the lack of knowledge in this sphere ("Yes, I want to improve my skills and make more money", "Yes, I know nothing about it and I have never tried"). As to the men, we assume that there is another mental difficulty which takes its roots from rural life, the first one is conservatism, and the second one is the fear of gossips and being called a shirker.

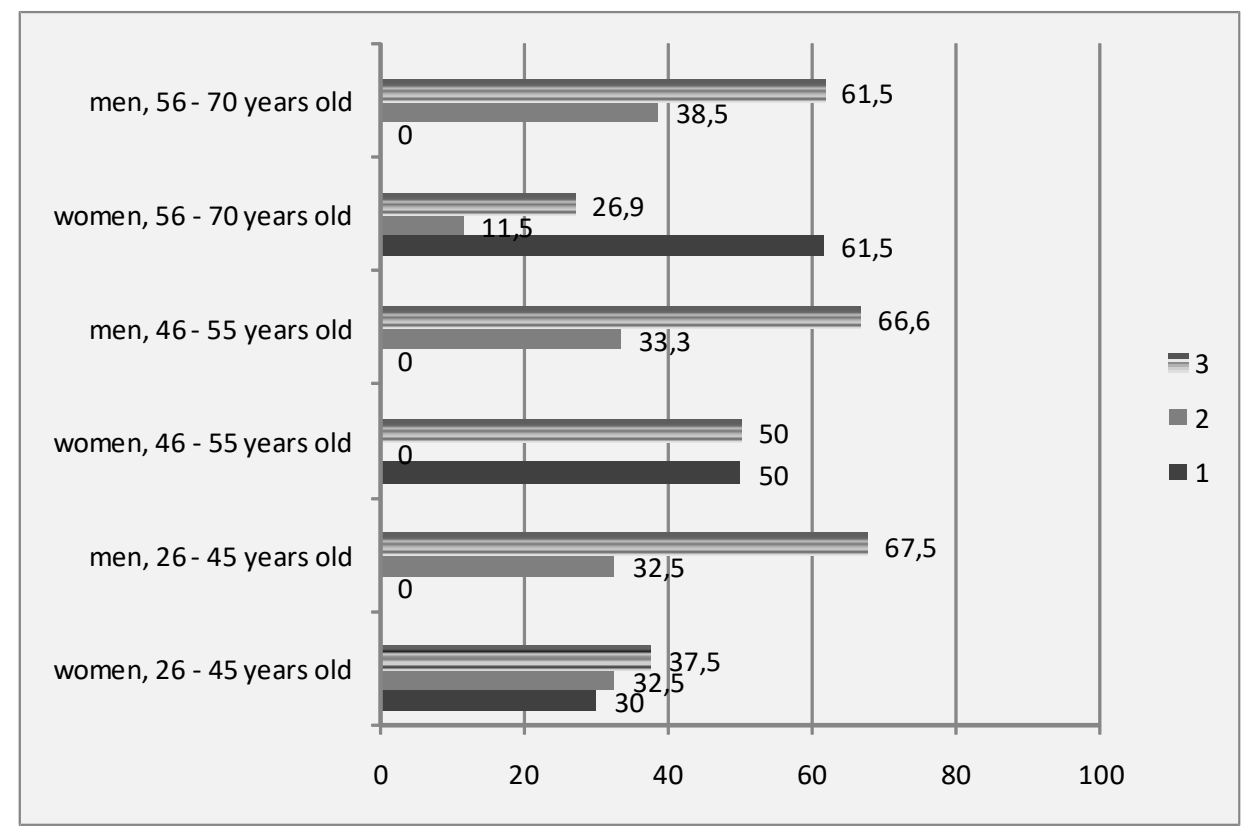

Fig. 2. Do you want to learn how to make extra money with the help of Internet? (women and men, $26-70$ years old, $\%)$.

\section{Discussion}

The statement of the research of Morozova T.V. et al. [2] made a few years earlier can be proved once again. The locals answer that the unemployment and low salaries are the ones. The worst point is that the situation has not changed to the better from that time and the social inequality between the countryside and the city has been still growing. That is why we see the out-migration from the countryside to cities and the rapid urbanization.

One of the solutions proposed by scientists to overcome rural unemployment and inequality is the urbanization creating agglomerations at list. The optimization of the expenses is the explanation of this theory which we assume as a very controversial one, especially talking about vast Russian surfaces. Rapid urbanization throws down new challenges to sustainable development and the development of green economy. For example, it impacts the regional environment as we can see in the research of E.A. Ivantsova [3].

There is the strong need to create a viable economic system in the countryside to unlock its potential and the potential of each individual as a component of economic system. There is also the need to increase the sense of community in the countryside the lack of which pointed Morozova T.V. et al. [2]. Another important need is to build the culture of selfsufficiency in the countryside. Such a system could be sustainable to external economic 
impacts and be able to cope with the reality globalization. It demands solid interconnection among different economic actors allocated around the rural territory. The objective of such interconnection is to increase and strengthen social ties, to promote and to sell goods and products with the expenses reduced.

We assume the Boudeville J.-R. [4] theory of the growth pole and the Friedman J. [5] theory of centre-periphery should be revised into the model of "growth territories". The "growth territories" interconnects several rural communities which are close to one another but are remote enough to favor from regional center development. The process of cooperating among close villages creates "growth territories" which facilitate the promotion and selling products and goods inside and outside compared with cooperating with the center. The strong need in developing such "growth territories" can be explained by the fact that Russian "growth centers" which are, as a rule, regional centers, cannot provide nor enough job places neither the infrastructure to raise modern quality of life.

It should be mentioned, that at its whole the population aspires to move to big cities, not regional cities, which cannot be fully called "growth centers", due to the same problems of unemployment and low salaries, as we find it in the research of Romashkina Yu.V. [6]. Abandoned vast natural territories and urbanization prevents from sustainable development and realization the concept of the green economy. According to Fedorova M.Y. [7] the majority of Russian surface with its rich and rare flora and fauna, plus architectural and cultural heritage, are being damaged and destroyed both by indifferent tourists coming from cities and marginalizing locals due to rural poverty and low level of life and values.

Another opinion takes into account the theories of endogenous or neo-endogenous development, or the more popular in Russia, the theory of self-development which seeks the "prosperity for a region" and improvement of social sphere, as it state Rostova O. et al.[8]. Researching the concept of self-development in the Russian Federation Tatarkin A. I. [9] assumes that creating agglomerations leads to the monopolization of markets and innovations by centers thanks to their higher growth potential. Moreover, nowadays there is no appropriate elaborated scientific strategy to create agglomerations.

We also assume that endogenous development of rural territories when locals are given more freedom to run their economy and resources would be more appropriate to reach economic and ecological prosperity for rural territories as it was pointed also by Kotler P. [10], Aleksandrov I.N. and Fedorova M. Yu. [11]. Following the concepts of endogenous and neo-endogenous development proposed by Steel C. E. and Mitchell C. J. A. [12] and Ray C. [13] rural territories could create "growth territories" providing "non-importables", as it is assumed by Van der Ploeg et. al. [14] and reach sustainability and the green economy. We also assume that the base the endogenous development of a territory must be constructed of its locals who run their own business. The raise of entrepreneurs who get profit both from importable and non-importable makes easier achieve the objectives of the theory of self-development. The tools of digital economy and the reality of post-industrial economy propose new options to less-favored far-away from center territories.

One of the attributes of the post-industrial economy is characterized a plethora of selfemployed individuals who can promote and sell their products to consumers or an organization directly. Intellectual services or physical goods can be realized thanks to the Internet and its services. For example, the research of Bahaman A. S. et al. [15] shows how rural community can benefit from using new Internet technologies. The research of Strebkov D. O. et al. [16] confirms that the market of freelancers tends decentralize from big cities to other regions of Russia, even to rural territories. But it should be mentioned that the share of freelancers in rural territories is at its minimum. Moreover, the share of freelancers of the Republic of Karelia according to the research of Strebkov D.O. et al. is too low, making only $1 \%$. We assume that freelancers are individuals who are creative, talented full of ideas. So, with the help of new technologies they can realize their goods 
and products, both importable and non-importable producing the added value in such a way.

According to the research of Strebkov D. O. et al. [16] the quantity of freelancers has been rising, they consider themselves as the self-employed peoples and are being in the process of transformation into entrepreneurs because at the present time they cannot start their entrepreneurial activity due to some circumstances. The research of Mukhanova M. N. [17] also demonstrates the raise of employed in the sphere of service at rural territories due to low salaries and unemployment in traditional sectors. That is why we assert that remote work or the use of Internet to promote and sell goods and services are the most evident and appropriate way to transform a rural individual into an entrepreneur. We assume that an individual will transform very naturally into an entrepreneur in case he or she develops in its profession, broadening social ties which is a must, when we talking about freelance work or real business, and even the model of creating "growth territories". We see such a development is the most desirable for a rural territory because thanks to an assortment of entrepreneurs the rural economic system becomes more resilient, gets more money for developing social infrastructure.

Another important point about digital tools beneficial for endogenous development of a territory is that at the present time, as Syssoeva N. M. [18] asserts, the majority of horizontal interlinkages in a community or among communities disappeared due to the state "manual regulation". The horizontal interlinkages among people in rural community are very important to build resilient and flexible economic system. At the time of peasantry, rural local communicated with the help of churches, the youth gathered not only for entrainment but to discuss important question of households. Nowadays, the infrastructure of rural territories is very poor. We cannot find, for example, cafes where people can discuss important problems, locals do not gather anywhere. So we see that the Internet could be the initial place to unite people and then to continue solve local challenges. We also find that realizing of different projects, as it is proposed by Bril A.R. [19] et al. by the community has the power to enhance the interconnections among locals. Projects, territorial problems, even the challenges to create new job opportunities could be discussed with the help of territorial crowdsourcing which is very desirable to be achieved instead of existing distance between the society and the state, as Simakova A.V. and Kozyreva G.B. [20] assert. We see that the Internet is the most feasible and real space to make the initial steps to gather the community and start finding and creating new importable and non-importable to make money for each individual and the territory at its whole. Whatever the digital economy and post-industrial economy makes individuals easier make money even in remote areas. But to make the economic system sustainable and more resilient to external shocks the community needs to create ties.

As to the segments of unemployed at rural territories, the research of Strebkov D. O. et al. [16] shows that the majority of unemployed rural population makes the youth from 25 years and middle-aged people from 56 years old. At the same time, the youth are the most sensitive to be integrated in the realm of new technologies and the use of Internet. It is also should be mentioned that the problem of unemployment and low salaries takes place not only among the youth. As a rule, the youth migrates to big cities. But the middle-aged people prefer to stay, return to their native place or to in-migrate to calmer place from a big city. That is why the problem of unemployment is also very important for them. This was proven by the research had been implemented by Sukneva S. A. et al. [22] and by our own field studies. According to the research of Sukneva S. A. et al. [22] the risk of poverty and the dissatisfaction by the quality of life makes rural people start farming $(88 \%)$. The share of the middle-aged people close to the retirement who starts farming makes $36,9 \%$. We assume that they could broaden the possibilities of making money with the help Internet tools, for example, using the Internet to sell their farm products. Another option for farmers 
to get extra money with the help of Internet is to teach other people farming or other niche skills.

As ErokhinV. et al. [23] assert, in the realm of post-industrial economy nonstandard forms of employment is an option to overcome poverty and unemployment in the countryside. That is why the economy of the rural territories should be diversified thanks to services. The traditional agricultural sphere does not supply nor enough job opportunities neither desirable salaries and standards of life. On the other hand, there is lack of qualified individuals at the countryside able to meet the needs of modern agricultural enterprises. That is also the challenge which should be solved with the help of the tools of digital services.

We assume that the remote work can be an option to diversify the labor market of the Russian rural countryside and to develop the entrepreneurship. Our research (Fig. 1) shows that the locals desire to make money on the Internet and with the help of digital tools. Moreover, they would like to improve their skills in this sphere (Fig. 2). The strong need of the diversification of rural market is also pointed by Zhirnel E.V. and Kulakova L.M. [24]. They also propose to create the market of both importable and non-importable in the countryside of the Republic of Karelia and assume that to create such a system of traditional methods do not work.

New job opportunities for the countryside are very important because there is an opinion that the level of rural unemployment is higher in reality in comparison to low statistics' data. The problem is that locals do not want to be registered as the unemployed. We also assume that locals do not register as the unemployed due to the fact that they do not know nor all the procedures neither where and what for they should be registered. For sure, job possibilities should be diversified instead of today's major agrarian jobs.

We assert that in the era of digitalization such a diversification can be implemented with the help of remote work and / or selling goods, products and "non-importables" via Internet. But our field research shows that today locals do not believe rural territory possesses any sort of resources which could be sold. That is why we see ubiquitous migration from the countryside to cities due to economic circumstances. Natural, architectural and cultural resources abovementioned as "non-importables" are not believed to be a potential capital to make money and to create the basis for the green economy. We assume the development of green economy is possible only in case locals realize the importance of conservation of natural and cultural resources, the authenticity of its region, see the profit he or she can get from the resources. At the present time, Russia needs creating more sources for renewable energy as Druzhinin P.V. [25] et al. shows the dependence between the development of economy and the economy based on power industry . Vast rural territories possess a variety of options for it. The endogenous model of regional development or the model of regional self-development is more feasible when the core actors of its system are entrepreneurs who take their market niche, cooperate with one another creating interconnections and strong power to resist the monopolization, take care of the environment as their main resource for sustainable life.

Another important point should be taken in mind is the authenticity of each region which is whatever intangible, but of great value for a territorial development commercializing its non-importables. The process of development has the risk to lance the process of destroying the territorial authenticity due to the globalization. As Stepanova S.V. and Shlapeko E.A. [26] quote even a handful of newcomers can cause misunderstandings. We also point that it can cause the damage of authentic territorial culture.

The question of the expenses needed to realize the program of Internet connections at rural areas can be arguable. But today, as also Simakova A.V. and Kozyreva G.B. [20] assume notably about the Republic of Karelia, the Internet connection to commercialize goods and services does not demand high expenses which are not possible to invest at the 
present time. Unfortunately, we cannot tell that all rural territories possess the Internet connection but we assume that the theory of "growth territories" are going to work with the help of developing territories which are now connected to the Internet both thanks to telephones and mobile phones.

As far as we see the great interest from rural locals to make money with the help of Internet, we assume that the role of the state in this question should be to create the environment for such a development. Teach people make money in the Internet and commercialize non-importables is the most important point to make them more resilient and self-efficient. We also see this as the initial step of the endogenous development of a rural territory.

\section{Conclusion}

In the era of post-industrial economy when the digitalization plays the core role in the diffusion of innovations and propose a wide range of new job opportunities new strategies and policies should be chosen to develop regional communities to make them prosperous. The prosperity of each community, notably, rural community, where locals suffer from unemployment and low salaries and cannot protect the environment, is one of the main to achieve the green economy in the realm of vast surfaces of Russia. Another point should be taken in mind is that there is a handful of people moving from big cities to villages. But we see that the main barrier to out-migration from cities to the countryside is the absence of medical and other infrastructure. That is why we assume that the village should be developed, but not abandoned because prosperous villages could help to lower the load on the city's infrastructure.

We assert that according to the endogenous or neo-endogenous theory the countryside should be given more freedom to make it develop. Such a development can be realized easier and faster in the framework of post-industrial and digital economy where the main products are services and they are commercialized with the help of Internet. Our research showed that the locals were interested in remote work and need extra salary. They also showed their interest in getting new knowledge of making money with the help of Internet. Comparing with the researches on the remote and alternative work of other rural territories of Russia we assume that the results of such a survey can be extrapolated. However, the scope of the research can be broadened with villages which are tinier or bigger, closer to the center or more remote, another important point we should take in mind is the availability of big enterprises on the territory.

We assume once again the viability of the theory of decentralization and natural settlements around rural territories of Russia, because the countryside provides natural resources and individuals working remotely or individuals selling physical products or "non-importables" on the Internet create added value to the economy of a territory. Whatever the Internet can be the space for commercializing products and services, the realm of digital economy opens the opportunities to create the more favorable space for interconnections among economic actors of each territory. We assume a special Internet network should be created to gather both internal and external economic actors.

\section{References}

1. P.A. Victor, T. Jackson, Towards a New, Green Economy (Centre for the Understanding of Sustainable Prosperity and Sustainability in the Green Economy, 2016) 
2. T.V. Morozova, G.B. Kozyreva, R.V. Belaya, M.V. Sukharev, E.A. Mikhel, M.V. Dyakonova, I.V. Timakov, A.A. Morozov, Transactions of KarRC RAS 3, 103-116 (2015) DOI: http://dx.doi.org/10.17076/reg71

3. E.A. Ivantsova, Science Journal of VolSU. Clobal Economic System 35(2), 148-159 (2016) DOI: http://dx.doi.Org/10.15688/jvolsu3.2016.2.15

4. J.-R, Boudeville, L'espace et les pôles de croissance (PUF, 1968)

5. J., Friedmann, Regional development policy: a case study of Venezuela (The MIT Press Ltd, 1966)

6. Yu.V. Romaskina, Russian J. of Labor Econ. 3 (2017) DOI: 10.18334/et.4.3.38237

7. M.Y., Fedorova, Reg. Prob. Transf. Econ. 3 (2017) DOI: https:// doi.org/10.26726/2305-4484-2017-3

8. O. Rostova, S. Shirokova, A. Shmeleva, MATEC Web Conf. 170, 01024 (2018) DOI: https://doi.org/10.1051/matecconf/201817001024

9. I. Tatarkin, A. Econ. \& Soc. Ch.: facts, trends, forecast 24, $42-59$ (2012)

10. P., Kotler, Confronting Capitalism: Real Solutions for a Troubled Economic System (AMACOM, 2015)

11. I.N. Aleksandrov, M.Yu. Fedorova, Sc. J. of KubSAU 10 (2017) DOI: 10.21515/19904665-134-063

12. C.E. Steel, C.J.A. Mitchell, J. Rural and Community Dev. 12, $55-74$ (2017) DOI:10.177/0969776414532932

13. C., Ray, Culture Economies: a perspective on local rural development in Europe (Centre for Rural Economy, Dept. of Agricultural Economies and Food Marketing, University of Newcastle upon Tyne, 2001)

14. Van der Ploeg, Sociol. Ruralis 40, 391 - 408 (2000). DOI: 10.1111/1467-9523.00156

15. Samah, H. Azril Mohamed Shaffril, J. Lawrence D'Silva, M. Abu Hassan, Asian Soc. Sci. 4, 136-144 (2010)

16. D.O. Strebkov, A.V. Shevchuk, M.O. Spirina, The Monitoring 6, 89-106 (2016) DOI: 10.14515/monitoring.2016.6.06

17. M.N. Mukhanova, Soc. J. 2(23), 74-95 (2017) DOI: 10.19181/socjour.2017.23.2.5161

18. N.M. Syssoeva, Quastiones Geographicae 29(2), 19-25 (2010) DOI: https://doi.org/10.2478/v10117-010-0011-8

19. A.R. Bril, O.V. Kalinina, I.V. Ilin, 2017 Proc. of the 29th IBIMA Vision 2020: Inn. Man., 2268 - 2278 (2017)

20. A.V. Simakova, G.B. Kozyreva, World Ec. Man. 18(1), 129-139 (2018) DOI: 10.25205/2542-0429-2018-18-1-129-139

21. A.D. Volkov, G.B. Kozyreva, J. Cre. Ec. 12(3), 271-284 (2018) DOI: 10.18334/ce.12.3.38875

22. S.A. Sukneva, A.S. Barashkova, A.B. Neustroeva, Reg. Econ.: Theory and Practice 15, 1251-1260 (2017) DOI: https://doi.org/10.24891/re.15.7.1251

23. V. Erokhin, W. Heijman, A. Ivolga, Visegrad J. Bioec. \& Sust. Dev. 1(3), 20-25 (2014) DOI: $10.2478 /$ vjbsd-2014-004

24. E.V. Zhirnel, L.M. Kulakova, Transactions of KarRC RAS 3, 35-34 (2015) DOI: 10.17076/reg82i

25. P.V. Druzhinin, A.P. Shcherbak, S.V. Tishkov, Stud. Russ. Econ. Dev. 29(3), 280-287 (2018) DOI: 10.1134/S1075700718030036 
26. E.A. Shlapeko, S.V. Stepanova, Geo. Polon. 91(3), 301-315 (2018) DOI: 10.7163/GPol.0122 